\title{
Early Urban Development in the Near East
}

\section{Citation}

Ur, Jason A., Philip Karsgaard, and Joan Oates. 2007. Early urban development in the Near East. Science 317(5842): 1188.

\section{Published Version}

doi:10.1126/science. 1138728

\section{Permanent link}

http://nrs.harvard.edu/urn-3:HUL.InstRepos:4259360

\section{Terms of Use}

This article was downloaded from Harvard University's DASH repository, and is made available under the terms and conditions applicable to Other Posted Material, as set forth at http:// nrs.harvard.edu/urn-3:HUL.InstRepos:dash.current.terms-of-use\#LAA

\section{Share Your Story}

The Harvard community has made this article openly available.

Please share how this access benefits you. Submit a story.

\section{Accessibility}




\section{Early Urban Development in the Near East \\ Jason A. Ur ${ }^{1 *}$, Philip Karsgaard ${ }^{2}$, and Joan Oates ${ }^{3}$}

Science Manuscript no. 1138728

\footnotetext{
${ }^{1}$ Harvard University Department of Anthropology, 11 Divinity Avenue, Cambridge, MA 02138 USA.

${ }^{2}$ Archaeology, University of Edinburgh, Old High School, Infirmary Street, Edinburgh EH1 1LT, UK.

${ }^{3} \mathrm{McDonald}$ Institute for Archaeological Research, University of Cambridge, Downing Street, Cambridge CB2 3ER, UK.

*To whom correspondence should be addressed. Email: jasonur@fas.harvard.edu
}

Published 31 August 2007, Science 317, 1188 (2007)

DOI: $10.1126 /$ science. 1138728 
It has been thought that the first cities in the Near East were spatially extensive and grew outward from a core nucleated village while maintaining a more or less constant density in terms of persons or households per unit of area. The general applicability outside of the Near East of this southern Mesopotamian-derived model has been questioned recently, and variations from it are increasingly recognized. We can now demonstrate that such variation was present at the beginnings of urbanism in the Near East as well.

We present here the results of a study of the evolution of urbanism at the site of Tell Brak, in northeastern Syria. We approach demographic scale, density, and patterns of growth by using the spatial distribution of chronologically sensitive surface artifacts as a proxy indicator for the distribution and density of ancient settlement (1). Our results show Brak's urban origins to be contemporary with the appearance of cities in southern Iraq, the region generally considered to be the birthplace of Mesopotamian cities; hence the emergence of urbanism in the Near East was a regionally multicentric process (2). The spatial patterning of its growth, however, diverges from the southern Mesopotamian model, with implications for underlying sociopolitical processes.

Urban growth at Brak began in the LC 2 period (c. 4200-3900 cal BC). Ceramics from that time were found in six discrete clusters of 2-4 ha throughout the outer settlement complex, generally 200-500 $\mathrm{m}$ from the central mound (Fig. 1a). At this time, the central mound was entirely settled, and recent excavations have uncovered architecture and artifacts suggestive of social stratification (3). We calculate the total settled area at 55 hectares, at a time when few contemporary settlements exceeded 3 hectares. Thus during the LC 2 period Brak witnessed the rapid formation of a spatially extensive settlement characterized by clusters of occupied space interspersed with vacant zones in the outer town. 
During the early- to mid-fourth millennium BC (LC 3-4: 3900-3400 cal BC, Fig. 1b) outer town settlement expanded inward. Many formerly unsettled areas were now filled. The central mound hosted large industrial structures and an at least one elaborately decorated temple. The total LC 3-4 settled area had grown to 130 ha. We interpret the abundance of surface ceramics as an indicator of increased density of occupation. Thus settlement density increased along with spatial extent. At this time, the largest of Brak’s neighbors reached only 15 ha, and only one contemporary settlement in southern Mesopotamia, Uruk, exceeded it in size (4).

This trajectory of urban growth from 4200-3400 cal BC must reflect changes in underlying social and political structures. The spatial separation between settlement clusters suggests social distance between discrete sub-communities. In this sense they resembled an exploded form of the later nucleated Mesopotamian city, where neighborhoods were divided not by space but by walls and limited points of access. At Brak, clustering may have resulted from maintenance of social distance by immigrant groups. Existing social mechanisms may not have been able to sustain increased density in a nucleated form.

This dispersed pattern suggests both dependence upon, but some autonomy from, the political power on the central mound. Previous research has assumed that centralized and hierarchical sociopolitical institutions created cities as functional adaptations to problems of political and economic organization. Recently, however, archaeologists increasingly appreciate the bottom-up, or emergent, properties of ancient settlements $(5,6)$. Elite coercion does not appear to be solely responsible for the initial development of urbanism at Brak. It seems likely that it was at least in part the unintended result of the actions of autonomous and nonhierarchically ranked groups. 
At the end of the fifth millennium BC, a spatially extensive settlement emerged at Tell Brak, along the northern arc of the Fertile Crescent. It differed from the densely settled and nucleated urban forms of the succeeding Bronze Age in that it was composed of multiple discrete pockets of settlement surrounded by areas of low density or no settlement. Urbanism at Tell Brak began in a spatially extensive form, and its growth pattern was one of increasing density with simultaneous inward expansion. This pattern suggests a greater role for non-centralized processes in the initial growth of Brak, lesser importance for centralized authority, and that the study of Mesopotamian urbanism must accommodate multiple models for the origins of cities.

\section{Figures}

Fig. 1. Distribution of surface artifacts at Tell Brak, in $100 \mathrm{~m}^{2}$ sherd collection units. a. LC 2 (c. 4200-3900 BC) ceramics; b. LC 3-4 (c. 3900-3400 BC) ceramics. 


\section{References}

1. Materials and methods are available as supporting material on Science Online.

2. J. Oates, A. McMahon, P. Karsgaard, S. al-Quntar, J. A. Ur, Antiquity (in press).

3. J. Oates, Proc. Brit. Acad. 131, 1 (2005).

4. U. Finkbeiner, Ed., Uruk Kampagne 35-37 1982-1984: Die archäologische Oberflächenuntersuchung (Survey) (Philipp von Zabern, Mainz am Rhein, 1991), pp.

5. R. J. McIntosh, Ancient Middle Niger: Urbanism and the Self-Organizing Landscape (Cambridge Univ. Press, Cambridge, 2005), pp.

6. J. S. Lansing, Ann Rev Anthropol 32, 183 (2003).

7. Funded by the British Academy, the McDonald Institute for Archaeological Research, the Society of Antiquaries, the Charlotte Bonham-Carter Charitable Trust, the University of Michigan, and Harvard University. We thank the Directorate General of Antiquities and Museums of the Syrian Arab Republic, B. Jamous, M. al-Maqdissi, E. Ghanem, and H. Wright.

\section{Supporting Online Material}

www.sciencemag.org

Materials and Methods

Fig. S1 

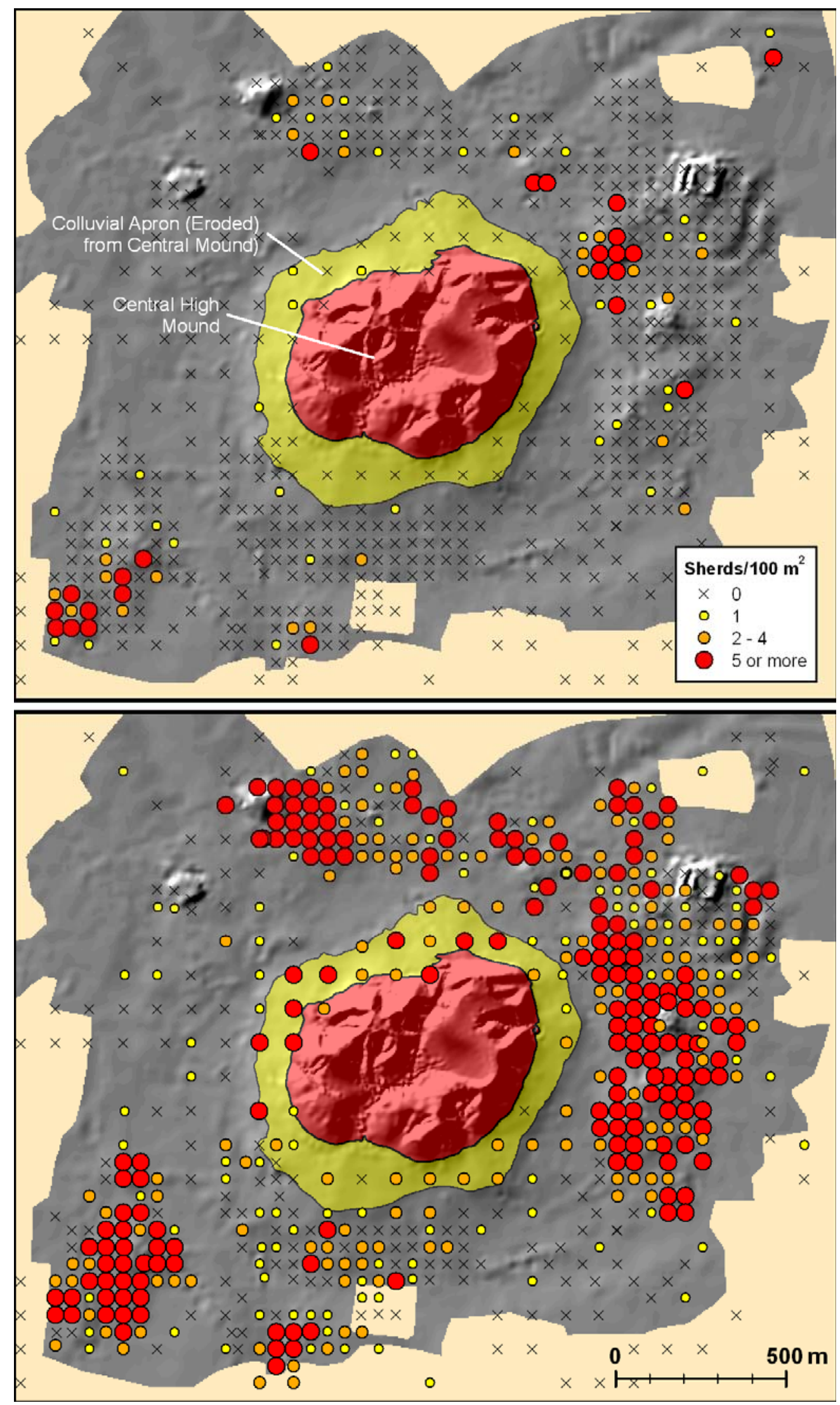


\section{Materials and Methods}

Our methods are based on the premise that the spatial distribution of discarded ceramics on the surface of an archaeological site can be used as a proxy indicator for the presence of past settlement. Archaeological materials make their way to the surface via a number of natural and cultural taphonomic processes, including erosion and wind deflation, human and animal excavations, and most prominently, agriculture. Almost the entire area of the Tell Brak outer town is currently under some form of cultivation; however, given the results of experimental studies of the lateral movement of surface artifacts under plowing conditions (S1-3), we regard the present position of surface artifacts to be a reliable indicator of the location of ancient settlement.

The long history of excavation on the central mound has seriously contaminated its surface ceramic assemblage; furthermore, these excavations have already provided a detailed overview of the history of this part of the settlement complex (S4). Therefore sampling was limited to the largely uninvestigated areas in the outer settlement, which represent over 75\% of the entire site. Following Whallon (S5), we adopted a systematic sampling strategy: collection units were placed at $50 \mathrm{~m}$ intervals in undisturbed areas of high surface visibility (mostly fallow or unplowed non-irrigated agricultural fields) and at $100 \mathrm{~m}$ intervals in disturbed areas or areas of low visibility (recently plowed ground, or areas of irrigation agriculture). Units were positioned using handheld Global Positioning System (GPS) receivers, with reference to the Universal Transverse Mercator (UTM) projection and coordinate system (Zone 37 north, WGS 1984 datum). Uncorrected GPS measurements in this long-deforested landscape have an estimated positioning error of between 4-5 m, an error determined to be acceptable, given the nature of surface ceramic assemblages as described above. In certain locations, it proved 
impossible to adhere strictly to our sampling grid, largely owing to local ground conditions (low visibility resulting from the presence of crops, roads and tracks, or modern buildings). In such situations, we either omitted a collection unit, or placed it off the grid but as close to the intended position as possible. In total, 963 units were positioned and collected in Brak's outer town and the adjacent landscape (Fig. S1).

The collection units themselves were $100 \mathrm{~m}^{2}$ areas in $10 \mathrm{~m} \times 10 \mathrm{~m}$ squares. Collection proceeded in one of two ways, based on an initial visual assessment of the ground conditions and surface sherd density. If density was low and/or if visibility was poor, all sherds from the entire $100 \mathrm{~m}^{2}$ were collected; these full collection units are labeled "field scatter" units. If density was high, all sherds were collected from a fraction of the full unit (generally a $2 \mathrm{~m}$ x $2 \mathrm{~m}$ area) while only chronologically distinctive sherds were collected (separately) from the rest of the $100 \mathrm{~m}^{2}$ unit. These units were labeled as "surface collection" units. This distinction allowed us to reduce the amount of ceramic materials to be analyzed from high-density areas, while still recovering comparable data on the density and chronological distribution of sherds in the unit. In total, over 55,000 sherds were collected and analyzed.

These ceramic collections were analyzed with reference to a working field typology based primarily on that of Wilkinson and Tucker (S6) and expanded and refined with reference to ceramics from the stratigraphic excavations on Brak's central mound $(S 7, S 8)$ and from surveys in nearby areas (S9). The excavated ceramic types have been closely dated by their contextual association with layers dated via C-14 (S10, S11).

In analyzing the resulting distribution of sherds, we have taken into account the dynamic geomorphology of the site itself (S12). Two processes are especially important. The first is natural: erosional processes have continually removed sediments and artifacts from the high 
central mound and redeposited them on the slopes immediately adjacent to it. These sherds are therefore disregarded in our assessment of settled area. The second process was a cultural one. The central high mound is separated from the outer settlement by a circular depression which averages $150 \mathrm{~m}$ in width. This depression resulted from the repeated excavation of material for the construction of mud brick architecture initially on the central mound but subsequently in the outer town as well. It therefore remains a possibility that some of the outer town may have been removed by Bronze Age brickmaking, especially since the major ancient leveling fills on the central mound contain abundant LC 3-4 ceramics. It is also possible that this circular depressed feature originated prior to or simultaneously with the initial urban expansion of the LC 2 period and continued to be used throughout the entire span of occupation on the high mound. We therefore suppose that, on the whole, it was never a locus of settlement. 
Fig. S1. Distribution of collection units on the outer mounds of Tell Brak. Gray shaded relief represents the limits of detailed topographic data. Contour interval $1 \mathrm{~m}$.

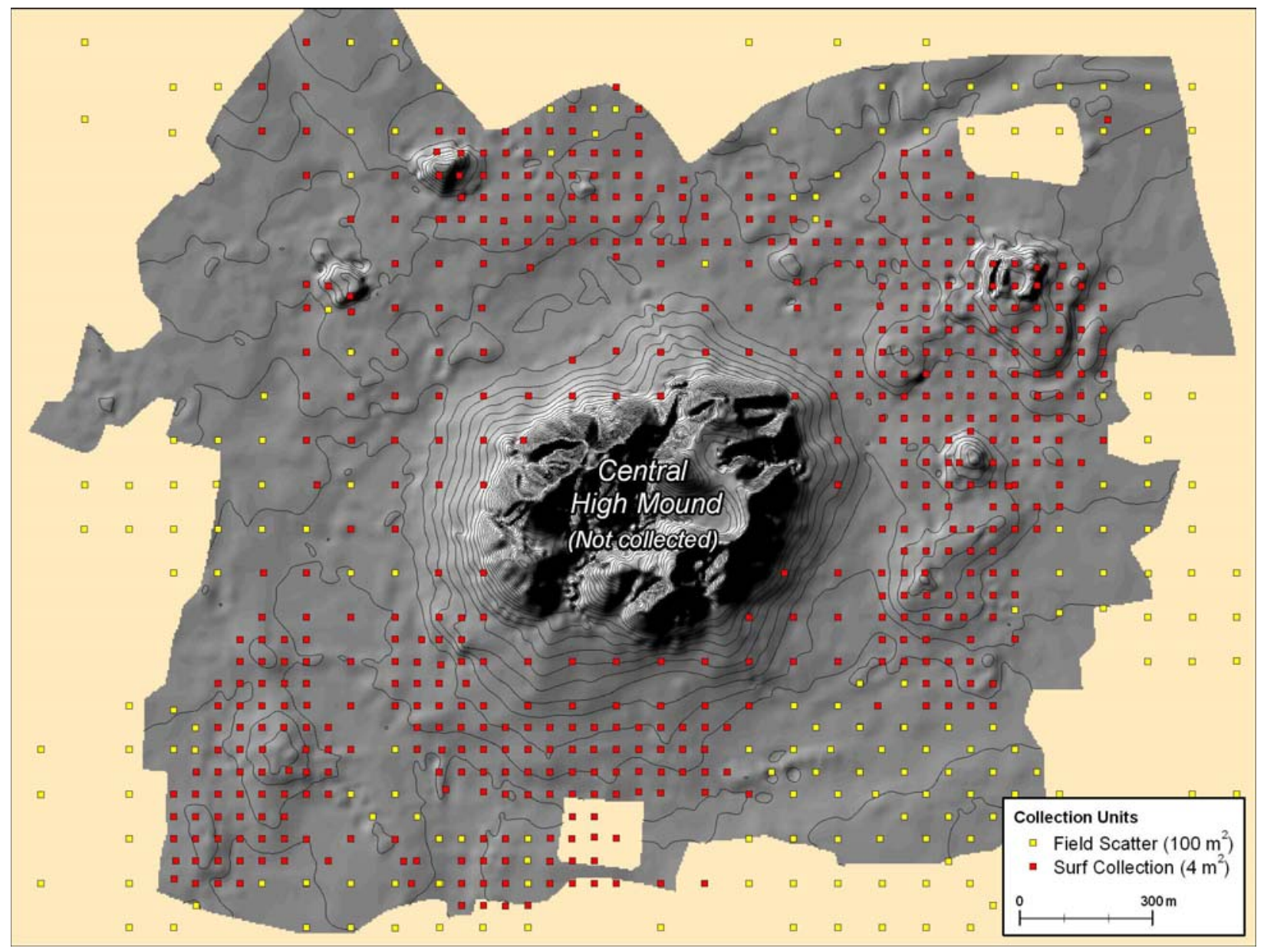

\section{References}

1. A. J. Ammerman, J. Field Archaeol. 12, 33 (1985).

2. $\quad$ K. G. Hirth, J. Field Archaeol. 5, 125 (1978).

3. D. C. Roper, Am. Antiq. 41, 372 (1976).

4. J. Oates, Proc. Brit. Acad. 131, 1 (2005).

5. R. Whallon, An Archaeological Survey of the Keban Reservoir Area of East-Central Turkey (Univ. of Michigan, Ann Arbor, 1979).

6. T. J. Wilkinson, D. J. Tucker, Settlement Development in the North Jazira, Iraq (Aris \& Phillips, Ltd, Warminster, 1995).

7. D. Oates, J. Oates, H. McDonald, Excavations at Tell Brak, Vol. 1: The Mitanni and Old Babylonian Periods (McDonald Institute for Archaeological Research and the British School of Archaeology in Iraq, Cambridge and London, 1997).

8. D. Oates, J. Oates, H. McDonald, Excavations at Tell Brak, Vol. 2: Nagar in the Third Millennium BC (McDonald Institute for Archaeological Research and the British School of Archaeology in Iraq, Cambridge and London, 2001). 
9. J. A. Ur, Akkadica 123, 57 (2002).

10. F. Hole, Iraq 63, 67 (2001).

11. H. T. Wright, E. S. A. Rupley, in Uruk Mesopotamia \& its Neighbors: Cross-Cultural Interactions in the Era of State Formation M. Rothman, Ed. (School of American Research Press, Santa Fe and Oxford, 2001) pp. 85-122.

12. T. J. Wilkinson, C. A. I. French, W. Matthews, J. Oates, in Excavations at Tell Brak, Vol. 2: Nagar in the Third Millennium BC D. Oates, J. Oates, H. McDonald, Eds. (McDonald Institute for Archaeological Research and the British School of Archaeology in Iraq, Cambridge and London, 2001) pp. 1-14. 